\title{
LATAR BELAKANG PENDIDIKAN ORANG TUA TERHADAP PERKEMBANGAN SOSIAL ANAK USIA 5-6 TAHUN
}

\author{
Tesi Ayi Nurlita ${ }^{1}$, Sumardi $^{2}$, Sima Mulyadi $^{3}$ \\ ${ }^{1}$ Universitas Pendidikan Indonesia Kampus Tasikmalaya \\ ${ }^{2}$ Universitas Pendidikan Indonesia Kampus Tasikmalaya \\ ${ }^{3}$ Universitas Pendidikan Indonesia Kampus Tasikmalaya \\ Email: tesiayi13@gmail.com
}

(Received: Mei 2020; Accepted: Mei 2020; Published: Juni 2020)

\begin{abstract}
This research is related to the educational background of parents towards the social development of children aged 5-6 years in the village of Cipertani. The research method used is descriptive qualitative with data collection techniques in the form of questionnaires to research respondents. Respondents in this study were 30 parents who have children aged 5-6 years living in the village Cipertani Rt.05 Rw.08. The educational background of parents in the Cipertani village of 30 respondents ranged from $26.7 \%$ of elementary school graduates, 6\% of junior high schools, $33.3 \%$ of high schools and $20 \%$ of universities. Children's social development includes the child's response to playing with peers, the child's cooperative nature, and the attitude of responsibility of the child. The child's social development questionnaire filled with parents includes both positive and negative statements with five alternative answers on a scale of 1-5. Children's social development is divided into four categories $<20 \%$ categorized as undeveloped, 20\% $-35 \%$ still developing, 36\% -65\% developing as expected, and 66-100\% developing very well. The social development of children in Cipertani village has an average of $47.18 \%$ categorized as developing according to expectations. The results of the regression test showed that the value of $P(P$-Value $)=0.315$ stated that Ho was rejected, so it can be concluded that the educational background of parents did not affect the social development of children aged 5-6 years in Cipertani village.
\end{abstract}

Keywords: Educational background; Social development; 5-6 years old;

\begin{abstract}
ABSTRAK
Penelitian ini berkaitan dengan latar belakang pendidikan orang tua terhadap perkembangan sosial anak usia 5-6 tahun di kampong Cipertani. Metode penelitian yang dipakai adalah kontitatif deskriptif dengan teknik pengumpulan data berupa penyebaran angket pada responden penelitian. Responden dalam penelitian ini adalah 30 orang tua yang memiliki anak usia 5-6 tahun tinggal di kampung Cipertani Rt.05 Rw.08. Latar belakang pendidikan orang tua di kampung cipertani dari 30 responden berkisar dari tamatan SD sederajat sebanyak 26,7\%, SMP sederajat sebanyak 6\%, SMA sederajat sebanyak 33,3\%, dan Perguruan Tinggi sebanyak $20 \%$. Perkembangan sosial anak mencakup respon anak bermain dengan teman sebayanya, sifat kooperatif anak, dan sikap tanggung jawab anak. Angket perkembangan social anak yang diisi orang tua mencakup pernyataan baik itu positif dan negatif dengan lima alternatif jawaban dengan skala nilai 1-5. Perkembangan social anak dibagi menjadi empat kategori < 20\% dikategorikan belum berkembang, 20\%$35 \%$ masih berkembang, 36\%-65\% berkembang sesuai harapan, dan 66-100\% berkembang sangat baik. Perkembangan sosial anak di kampung Cipertani mempunyai rata-rata 47,18\% dikategorikan ke dalam berkembang sesuai harapan. Hasil penelitian uji regresi menunjukan nilai $\mathrm{P}(\mathrm{P}-\mathrm{Value})=0,315$ dinyatakan bahwa Ho ditolak maka dapat disimpulkan bahwa latar belakang pendidikan orang tua tidak berpengaruh terhadap perkembangan social anak usi 5-6 tahun di kampung Cipertani.
\end{abstract}

Kata Kunci: Latar Pendidikan, Perkembangan Sosial, Anak Usia 5-6 Tahun. 


\section{PENDAHULUAN}

Abad 21 ini pendidikan semakin berkembang dengan seiring berkembangnya teknologi yang semakin maju. Kemajuan teknologi membuktikan bahwa manusia semakin berkembang, berkembangnya kehidupan manusia sejalan dengan perkembangan pendidikan yang terus diinovasi seiring berkembangnya peradaban manusia. Mau tidak mau manusia harus mengembangkan pendidikan agar sejalan dengan kemajuan zaman yang semakin berkembang.

Latar belakang pendidikan seseorang tentu banyak berpengerauh pada pengetahun serta tingkah lakunya di masyarakat, karena pendidikan berhubungan dengan pengembangan aspek kognitif, afektif dan psikomotor. Oleh sebab itu orang dengan latar belakang pendidikan dianggap memiliki pengetetahuan serta keterampilan yang lebih banyak dikembangkan. Dikaitkan dengan orang tua yang memiliki latar belakang pendidikan tinggi makan dianggap lebih dapat mencontohkan dan mengajarkan berbagai hal pada anaknya. Oleh sebab itu perkembangan anak akan berkembang lebih baik khususnya dalam bidang perkembangan sosial, dimana dalam usia anak bersosialisasi dan berinteraksi dengan lingkungannya membuat anak belajar banyak hal. Itu sebabnya penting mengembangkan perkembangan sosial anak.

Pendidikan pun diadakan dan disesuaikan dengan perkembangan dan kematangan manusia. Karena disesuaikan dengan perkembangan manusia, di bagilah pendidikan menjadi beberapa jenjang, untuk menyesuaikan dan mengoptimalkan seluruh aspek perkembangan yang dimiliki setiap individunya. UU No. 20 Tahun 2003 Bab I, Pasal 1 Ayat 8 menegaskan bahwa jenjang pendidikan adalah tahapan pendidikan yang ditetapkan berdasarkan tingkat perkembangan peserta didik, tujuan yang akan dicapai, dan kemampuan yang dikembangkan. Jenjang pendidikan formal terdiri atas pendidikan dasar, pendidikan menengah, dan pendidikan tinggi.
Jenjang pendidikan paling awal dapat diperoleh di Pendidikan Anak Usia Dini (PAUD) yang disediakan bagi anakanak mulai usia nol sampai usia enam tahun yang bertujuan untuk menstimulus seluruh aspek perkembangan anak usia dini, serta menyiapkan anak untuk melanjutkan pendidikan ke jenjang berikutnya.

Selanjutnya jenjang pendidikan dasar dapat ditempuh 9 tahun di Sekolah Dasar (SD atau sederjat) dan Sekolah Menengah Pertama (SMP atau sederajat). Di Sekolah Dasar untuk lulus harus menempuh 6 tingkatan atau kelas selama enam tahun, selanjutnya siswa yang telah lulus sekolah dasar dapat langsung menempuh Sekolah Menengah Pertama (SMP atau sederajat) terdapat 3 tingkatan kelas di SMP yang harus di selesaikan selama 3 tahun. Jadi untuk menyelesaikan Pendidikan dasar normalnya membutuhkan waktu 9 tahun di SD dan di SMP.

Jenjang selanjutnya yaitu pendidikan menengah yang di selenggarakan di Sekolah Menengah Atas (SMA atau sejenis), jenjang ini dapat ditempuh dengan persyaratan siswa telah lulus pendidikan dasar sebelumnya. Sekolah Menengah Atas memiliki tiga tingkatan yang harus diseesaikan, normalnya siswa dapat lulus setelah tiga tahun pembelajaran. Kemudian jenjeng pendidikan tinggi yang diadakan di Perguruan Tinggi seperti Universitas, Institut dan sejenisnya. Pendidikan tersebut diadakan secara berkesinambungan dan terprogram.

Semakin tinggi jenjang pendidikan semakin semkin kompleks dan luas ilmu yang dipelajari. Sebaliknya pada tahap awal masa pendidikan di jenjang Pendidikan Anak Usia Dini, pembelajaran dikemas secara menyenangkan dan hal yang dipelajari harus konkret atau nyata berkaitan dengan lingkungan yang dekat dengan anak. Mengapa harus secara konkret dan menyenangkan? Karena pendidikan anak usia dini menyesuaikan dengan karakteristik anak yang unik, pengetahuan yang harus dibangun dari benda disekitarnya serta pembelajaran 
harus dikemas supaya menyenangkan agar anak dapat fokus pada pembelajaran.

Pendidikan yang menyenangkan bagi anak diselenggarakan di Pendidikan Anak Usia Dini untuk menyiapkan jasmani dan rohani anak agar siap menuntut ilmu ke jenjang selanjutnya. Sejalan dengan pernyataan tersebut ditegaskan pula dalam UU No.20 tahun 2003 tentang Sistem Pendidikan Nasional dalam pasal 1 ayat 14 bahwa Pendidikan anak usia dini merupakan suatu upaya pembinaan yang ditujukan bagi anak usia sejak lahir sampai usia enam tahun, dilakukan melalui rangsangan pendidikan untuk membantu pertumbuhan dan perkembangan jasmani serta rohani agar anak memiliki kesiapan untuk memasuki pendidikan lebih lanjut.

Untuk menyiapkan anak memasuki pendidikan lebih lanjut, anak mebutuhkan bimbingan berupa rangsangan agar pertumbuhan dan perkembangannya dapat optimal. Agar pertumbuhan dan perkembangannya optimal maka dikerucutkan ada 6 aspek perkembangan yang perlu distimulasi yaitu aspek nilai moral agama, aspek fisik motorik, aspek kognitif, aspek sosial emosional, aspek bahasa, dan aspek seni.

Pentingnya keenam aspek tersebut dikembangkan untuk membentuk karakter serta pengetahuan anak dan pengenalan lingkungannya. Pengenalan lingkungan penting dipelajari anak agar anak dapat menyesuaikan diri serta bersosialiasi secara aktiv dengan lingkungan sekitarnya. Salah satu aspek penting yang perlu dikembangkan sejak dini adalah aspek sosial anak. Aspek tersebut dapat membantu anak bertahan hidup dilingkungannya. Karena manusia pada hakikatnya merupakan mahluk sosial yang hidup berdampingan satu sama lainnya. Selaras dengan pernyataan Aristoteles menyebutkan bahwa manusia sebagai zoon politicon, yang berarti manusia dikodratkan untuk hidup bermasyarakat dan berinteraksi satu sama lain, dengan kata lain bahwa manusia sebagai mahluk sosial. Sosialisasi dilakukan manusia dengan berinteraksi antara individu membentuk relasi dan hubungan. Seperti yang telah dijelaskan bahwa manusia hidup dengan saling mebutuhkan dalam artian mahluk sosial, yang bertujuan saling memenuhi kebutuhan dengan berinteraksi sosial dan bekerja sama dengan sesamanya.

Penelitian ini merupakan penelitian lanjutan dari penilitian terdahulu Yuli Setyowati (2005: hlm. 75-76) yang mengemukakan dalam hasil penelitian yang dilakukannya mengenai komunikasi dan interaksi dalam keluarga, penelitian menyebutkan responden yang terlibat 18 keluarga dengan etnis jawa. Fakta yang didapatkan kebanyakan keluarga masih belum menyadari pentingnya interaksi dan komonikasi berpengaruh dalam perkembangan sosial anak. Interaksi keluarga hanya diyakini sebagai rutinitas bukan sesuatu yang dapat memberi arti dalam perkembangan anak.

Oleh karena itu, berdasarkan fakta bahwa manusia merupakan mahluk sosial yang tidak akan luput dari komunkasi, serta manusia hidup bekerja sama untuk saling membantu mengatasi masalah satu sama lain, peneliti ingin mnegetahui bagaimana jenjang pendidikan orang tua berpengaruh pada kemanpuan sosial anak usia 5-6 tahun. Sehingga muncul keinginan peneliti untuk meneliti lebih lanjut tentang Pengaruh jenjang pendidikan orang tua terhadap kemanpuan sosial anak usia dini.

\section{TINJAUAN PUSTAKA}

\section{A. Latar Belakang Pendidikan Orang Tua}

Latar belakang adalah titik tolak atau pencapaian seseorang hingga menjadi dirinya saat ini. Latar belakang sesorang banyaknya memiliki pengaruh untuk kelangsungan masa depannya. Sebagai contoh kebanyakan orang dengan latar belakang pendidikan Sarjana di bidang pendidikan, maka mayoritas diantaranya menjadi guru atau dosen, hanya sedikit diantaranya yang mengambil profesi yang tidak sejalan dengan latar belakang pendidikannya. Begitu pula dengan latar belakang pendidikan lainnya.

Kita ketahui, setiap orang memiliki latar belakang pendidikan yang berbeda. Karenanya pencapaian hidup akan berbeda setiap orangnya. Tentu 
kelangsungan dimasa depan tidak hanya bergantung pada latar belakang pendidikan. Latar belakang keluarga, latar belakang perekonomian, latar belakang lingkungan dan lainnya juga berperan dalam kelangsungan hidup seseorang dimasa depan. Namun, pendididikan merupakan sesuatu yang sangat penting bagi perkembangan manusia.

Dalam penyelenggaraan pendidikan tentu ada tujuan jelas yang ingin dicapai. Salah satu tujuan yaitu mengembangkan seluhuh potensi serta sapek-aspek perkembangan yang dimiliki anak. Dalam jurnalnya Mayar (2013, hlm. 460) Perkembangan merupakan perubahan yang sifatnya bukan kuantitatif atau hitungan, perkembangan bersifat kualitatif. Perkembangan dilihat pada segi fungsional, bukan dari segi material. Selanjutnya Hurlock E (1978) menyatakan bahwa perkembangan sosial memiliki arti pemerolehan diri akan kemempuan berlaku di lingkungan yang sesuai dengan tuntutan sosial sehingga dapat diterima di lingkungan sosialnya.

\section{B. Perkembangan Sosial Anak}

Dalam jurnalnya Mayar, Farida (2013:460) Perkembangan merupakan perubahan yang sifatnya bukan kuantitatif atau hitungan, perkembangan bersifat kualitatif. Perkembangan dilihat pada segi fungsional, bukan dari segi material. Menurut Yusuf (2001:15) makna perkembangan merupakan proses perubahan seseorang menuju kedewasaan atau kematangan yang dialui secara sistematis, progresif, dan berkesinambungan oleh individu atau organisme baik itu menyangkut fisik maupun psikis.

Selanjutnya Hurlock E (1978) menyatakan bahwa perkembangan sosial memiliki arti pemerolehan diri akan kemempuan berlaku di lingkungan yang sesuai dengan tuntutan sosial sehingga dapat diterima di lingkungan sosialnya. Menurut Hurlock E (1978) ada tiga proses agar dapat diterima di lingkungan sosial yaitu:

a. Individu harus belajar berprilaku sosial agar dapat diterima di lingkungan sosial. b. Individu memainkan peran sosial yang dapat diterima.

c. Perkembangan sikap sosial.

Perkembangan sosial anak akan berkembang secara optimal jika faktorfaktor yang mendukung perkembangan tersebut berperan positif bagi perkembangannya. Faktor-faktor yang mempengaruhi perkembangan sosial anak menurut Hurlock (1995) yaitu:

1) Faktor Lingkungan Keluarga

Mencapai kematangan sosial didapatkan ketika anak belajar cara-cara menyesuaikan diri dengan orang lain di lingkungannya. Kemampuan ini diperoleh anak dari krsrmpatan-kesematan juga pengalamnya berbaur dan bergaul dengan orang-orang disekitarnya, seperti dengan teman, orang tua, tetangga dan saudarasaudaranya. Lingkungan sosial yang pertama kali dipelajarinya adalah dilingkungan keluarga, karena keluarga merupakan lingkungan sosial terdekat bagi anak (Farida Mayar, 2013, hlm. 461463). Perkembangan sosial di lingkungan keluarga juga dipengaruhi oleh beberapa faktor yaitu: 1) status keluarga, Cara seseoang bersosialisasi akan sipengaruhi statusnya dalam keluarga, dikeluarganya berposisi sebagai adik, kakak, anak dan lainnya. Hal tersebutlah yang akan mempengaruhi bagaimana cara dia bersosialisasi, harus seperti apa dia bertindak ketika dia berposisi sebagai anak, adik atau kakak. 2) Keutuhan keluarga, Pengaruh selanjutnya yaitu keutuhan keluarga, keharmonisan dalam keluarga serta konflik yang minim didalamnya, akan membuat sosialisasi anak dapat berjalan lancar, karena tidak adanya hambatan yang mengganggu terjadinya proses sosialisasi anak. 3) sikap serta kebiasan orang tua, Karena anak menyerap informasi dari lingkungannya, maka anak akan mendupikasi dan meniru bagaimana cara orangtuanya bertindak dan berprilaku setiapharinya. Hal tersebut mempengaruhi sosial anak pula, jika orang tua memiliki sikap serta kebiasaan yang baik, maka dipastikan pula anak aan menirunya dan berprilaku baik pula, itu mendorong sosialiasi anak dengan lingkungannya menjadi optimal. 
2) Faktor Dari Luar Rumah

Sosialisasi di luar rumah merupakan wadah baginya untuk mempelajari lingkungan dan keadaan selain di rumahnya. Di luar rumah anak akan menemui banyak orang dengan banyak kepribadian seperti teman sebaya, orang dewasa, tetangga guru dan lainnya sehingga sosialisasinya akan berjalan sesuai dengan perannya di lingkungan tersebut.

3) Faktor Pengaruh Pengalaman Sosial Anak

Ketika seorang anak memiliki hambatan sosial karena pengalaman buruk akan hal tertentu, hal tersebut akan mempengaruhi proses sosialnya bersama lingkungan sekitarnya seperti tetangga dan teman sebayanya. Keadaan tersebut menyebabkan anak kurang berinteraksi serta bersosialisasi dengan lingkungan di luar rumah (Farida Mayar : 2013).

\section{Tahap Perkembangan Sosial Anak Usia 5-6 Tahun}

Sepanjang hidup manusia pasti mengalami perkembangan dari dia kecil sampai usia tua. Perkembangan sepanjang hayat tersebut menurut Erikson terbagi dalam delapan tahapan yang dalam masing-masing tahapan memiliki nilai positif dan negatifnya. Erikson juga menambahkan bahwa kesulitan yang dilaui pada setiap tahapan perkembangan yang disebutnya krisis atau konflik yang mempunyai sifat sosial serta psikologis yang sangat berarti bagi kelangsungan masa depannya. Perkembangan anak usia 5-6 taun menurut Erikson ada pada tahap Inisiatif Vs Rasa Bersalah (3-6 Tahun) (Yeni Krismawat : 2014). Pembangian menjadi tahapan perkembangan menurut Erikson adalah sebagai berikut (Yeni Krismawat : 2014):

1. Percaya Vs ketidakpercayaan

Tahap pertama yang erikson identifikasikan adalah basic trust versus basic mistrust (tahap kepercayaan dasar versus ketidakpercayaan dasar). Masa bayi masa ketergantungan atau masa dimana anak sangat membutuhkan orang lain untuk mengembangkan ketergantungan pada orang lain serta objek di dunianya.
Dalam tahap ini bayi akan berusaha mengembangkan keseimbangan anatra rasa percaya dan rasa ketidakpercayaan terhadap orang lain. Mereka akan menciptakan hubungan yang rapat terhadap orang yang mereka percayai dan sebaiknya pada orang lain akan menciptakan kewaspadaan pada diri mereka yang menimbulkan perilaku perlindungan diri. Bila rasa percaya mereka kepada salah satu orang muncul, akan berkembang "Virtue of hope" atau dapat diartikan bahwa orang tersebut dapat memenuhi kebutuhan mereka serta menyediakan apa yang mereka inginkan.

Tahap ini bayi akan keterikatan (attachment) pada ibu atau pengasuhnya. Keterikatan tersebut sangat adaptif bagi bayi, memastikan kebutuhan psikososial dan fisiknya harus terpenuhi.

Dalam mengembangkan kepercaan diri teradap lingkungannya ibu atau orangtua sangat berperan penting sebagai orang utama yang memberinya pembelajaran hidup. Kebutuhan akan rasa aman dan ketidakberdayaan menyebabkan konflik basic trust atau mistrust, dalam hal ini jika bayi tidak mendapatkan rasa aman akan berpengaruh terhadap kepercayan diri untuk berinteraksi dengan orang lain dilingkungannya. Sebaliknya jika bayi mendapat rasa nyaman dari orangtua mereka, mereka akan mudah mengembangkan rasa percayadiri terhadap lingkungannya dan dapat berbaur dengan baik tanpa rasa was-was akan bertemu orang baru.

2. Penguasan Vs malu dan ragu (18 bulan-3 tahun)

Tahap selanjutnya dimana anak mulai mengembangkan konsep kesadaran diri atau (i-self), konsep serta kesadaran akan diri mulai muncul pada usia 15 bulan. Konsep kesadaran ini pulan mendorong anak untuk bisa mengenali dirinya sendiri, memenuh apa yang diinginkannya, serta berusaha melakukan sesuatu dalam memenuhi atau mencapai kebutuhannya.

Dalam tahap ini toilet training mulai dapat diajarkan, dimana pengajaran tersbut mendorong anak mempelajari langkah penting menuju otonomi dan control dirinya. Pada usia tersebut anak 
akan memiliki dorongan rasa malu dan bersalah jika dia gagal melakukan apa yang diajarkan sebelumnya, dorongan rasa malu ditunjukan sebagai dorongan menyembunyikan wajah sendiri dari penglihatan orang.

Pada tahap ini pula anak mulai dapat melakukan beberapa aktivitas dengan mandiri, seperti menyendokan makannannya sendiri, menyampaikan keinginannya dengan berbicara dan berjalan. Kepercayaan orang tua terhadap anaknya, yakin bahwa memberikan kesempatan untuk bereksplorasi serta mencoba hal-hal baru dibawah pengawan dapat membentuk anak menjadi diri yang dapat mengandalkan dirinya sendiri atau mandiri dan anak dapat menjadi pribadi yang percaya diri.

3. Inisiatif vs Rasa Bersalah (3-6 Tahun)

Setelah tahapan sebelumnya yaitu mengembangkan mandiri serta rasa percaya diri anak, selanjutnya pada tahapan ini anak akan melai mengembangkan kemampuan inisiatifnya yang dapat dijabarkan dengan anak memiliki rasa bebas untuk melakukan apa yang dia ingin lakukan ataus sesuai dengan kehendaknya.

Dalam masa ini kemampuan motorik dan bahasanya akan terus berkembang memungkinkan mereka makin kuat dan agresif terhadap lingkungannya begitupun kemampuan fisik yang semakin meningkat. Mulai dari usia ini anak akan banyak berinisiatif dengan dorongan-drongan dari lingkungannya seperti dorongan orang tua, sodara, dan orang-orang disekitarnya berpotensi membuat anak untuk mulai dapat berlari, melompat, bermain, meluncur serta melempar. Karena dia mulai meyakakini serta menyadari bahwa dia adalah individu yang utuh, anak akan mencari dan menemukan akan menjadi orang seperti apa dia. Namun ketika orang tua tidak mendukung inisiatif anak atau menentang apa yang anaknya ingin lakukan akan menjadikan anak tersebut merasa bersalah.

Manusia merupakan mahluk sosial, dalam artian manusia akan memerlukan manusia lain dalam memenuhi kebutuhan hidupnya. Untuk dapat hidup bersosial dengan orang lain mausia harus memiliki keterampilan bersosialisasi dan menyesuaikan diri. Keterampilan sosial mulai dapat di rangsang pada anak sejak usia dini.

Untuk mengembangkan aspek sosial anak, orang tua berperan penting dalam mengoptimalkan perkembangan sosial anak. Bagaimanapun orang tua merupakan orang terdekat dilingkungan anak dan anak akan menjadikan orang tua sebagai model serta teladan baginya. Keterampilan orang tua dalam merangsang serta menstimulus perkembangan anak sangat membantu anak dalam tahap pertumbuhan serta perkembangannya termasuk dalam aspek perkembangan sosialnya.

Jadi begitu dominannya orang tua berpengaruh besar dalam proses perkembangan anak. Untuk mengoptimalkan proses perkembangan anak sejak dini, orang tua memiliki cara yang berbeda dalam mendidik serta menstimulasi perkembangan anak. Cara mendidik tersebut tentu dipengaruhi oleh edukasi yang di dapat orang tua sebelumnya. Maka pendidikan orang tua juga berperan penting dalam mempengaruri pola asuh dan didikan yang diterapkan prang tua. Maka melalui penelitian ini peneliti ingin mengetahui bagaimana jenjang pendidikan yang ditempuh orang tua berkaitan dengan berkembangnya perkembangan sosial anak usia 5-6 tahun (Yeni Krismawat : 2014).

\section{METODE}

A. Desain penelitian

Penelitian ini mengguakan Pendekatan Kuantitatif dengan teknik pengumpulan data melalui penyebaran angket (questionnaire) kepada responden. Penelitian kuantitatif sendiri menurut Instrument yang digunakan adalah pengumpulan data berupa angket terdiri dari daftar pertanyaan yang diberikan pada orang lain yang menjadi responden sesuai dengan permintaan pengguna.

\section{B. Partisipan dan Lokasi Penelitian}

Subjek yang dituju dalam penelitian ini adalah para orang tua yang memiliki anak usia 5-6 tahun yang 
bertempat tinggal di Kampung Cipertani. Penelitian ini lakukan di Kampung Cipertani, RT.005/RW.008, Desa Karangmekar, Kecamatan Karangnunggal, Kabupaten Tasikmalaya.

Pengambilan subjek penelitian dilakukan dengan menggunakan sempling jenuh (sampel sensus), atau keseluruhan populasi orang tua di kampong Cipertani yang memiliki anak usia 5-6 tahun yang berjumlah 30 responden. Teknik sampling jenuh yaitu metode pengambilan sampel dimana subjek penelitian dipakai karena keseluhuran populasi orang tua yang memiliki anak usia 5-6 tahun di kampong cipertani tidak terlalu banyak dan memungkinkan seluruh populasi untuk diikut sertakan menjadi responden penelitian.

Pengambilan subjek penelitian dilakukan dengan menggunakan sempling jenuh (sampel sensus), atau keseluruhan populasi orang tua di kampung Cipertani yang memiliki anak usia 5-6 tahun yang berjumlah 30 responden. Teknik sampling jenuh yaitu metode pengambilan sampel dimana subjek penelitian dipakai karena keseluhuran populasi orang tua yang memiliki anak usia 5-6 tahun di kampung Cipertani tidak terlalu banyak dan memungkinkan seluruh populasi untuk diikut sertakan menjadi responden penelitian.

\section{Pengumpulan Data}

Teknik pengumpulan data pada penelitian ini menggunakan teknik kuisioner. Lembar kuisioner yang digunakan sebagai alat menggunakan bentuk rating-scale dimana rating tersebut menentukan himpunan skor yang didapat, peneliti harus dapat mengartikan setiap angkat atau symbol yang di tentukan dandi pilih sebagi alternative jawaban pada setiap item instrument (Sugiono, 2011 : 141). Kuisioner ini menyediaka 5 alternative jawaban yang bernilai (5), (4), (3), (2), dan (1). Alternatif jawaban di sediakan menggunakan angka yang merepresentasikan nilai (5) untuk Sangat Sering (SS), (4) untuk Sering (SR), (3) untuk Kadang-Kadang (KK), (2) untuk Jarang (JR), (1) untuk Sangat Jarang (SJ).
Lembar kuisioner diisi dengan melingkari salah satu alternatif jawaban.

Setelah data dihimpun dari responden, langkah selanjutnya merupakan analisis data dan pengolahan data. Dengan dilakukannya pengolahan data peneliti dapat menjawab pertanyaanpertanyaan yang telah dilampirkan pada rumusan masalah. Karena peneliti melakukan pengumpulan data dengan teknik Kuisioner berupa angka-angka, selanjutnya data tersebut diolah dengan cara dihimpun dalam aplikasi SPSS, untuk diidentifikasi. Langkah analisa data dilakukan untuk memenuhi tujuan penelitian, dengan tahapan-tahapan deskripsi data, uji persyaratan analisis dan terakhir yaitu uji hipotesis.

Tabel 1. Kriteria Penilaian Tingkat Kecenderungan

\begin{tabular}{cc}
\hline Rentang Skor & Interpretasi \\
\hline $\mathrm{X}>\mathrm{Mi}+1$ SDi & Sangat Tinggi \\
$\mathrm{Mi}<\mathrm{X}<\mathrm{Mi}+1 \mathrm{SDi}$ & Tinggi \\
$(\mathrm{Mi}-1 \mathrm{SDi})<\mathrm{X}<$ & Rendah \\
$\mathrm{Mi}$ & \\
$\mathrm{X}<\mathrm{Mi}-1 \mathrm{SDi}$ & Sangat Rendah \\
\hline
\end{tabular}

\section{Analisis Data}

Menurut Bongdan (dalam Sugiyono: 2013, hlm. 334) analisis data adalah proses mencari dan menyusun secara sistematis data yang diperoleh dari hasil wawancara, catatan lapangan, dan bahan-bahan lainnya sehingga dapat mudah dipahami, dan temuannya dapat diinformasikan kepada orang lain.

Setelah data dihimpun dari responden, langkah selanjutnya merupakan analisis data dan pengolahan data. Dengan dilakukannya pengolahan data peneliti dapat menjawab pertanyaanpertanyaan yang telah dilampirkan pada rumusan masalah. Karena peneliti melakukan pengumpulan data dengan teknik Kuisioner berupa angka-angka, selanjutnya data tersebut diolah dengan cara dihimpun dalam program pengolahan data Excel dan SPSS, untuk diidentifikasi. Langkah analisa data dilakukan untuk memenuhi tujuan penelitian, dengan tahapan-tahapan deskripsi data, uji persyaratan analisis dan terakhir yaitu uji hipotesis. 


\section{E. Isu Etik}

Penelitian ini merupakan analisis dari latar belakang pendidikan orang tua terhadap capaian perkembangan anak usia 5-6 tahun. Dimana akan menganalisis perkembangan sosial anak yang tentunya hasil dari didikan orang tua mereka, bagaimana orang tua berperan langsung dalam perkembangan anak serta mengetahui seberapa jauh anak mereka berkembang. Pelitian ini meminialkan dampak negative yang akan terjadi setelah penelitian dilakukan. Sehingga peneliti merahasikan identitas responden serta data-data yang responden berikan berupa identitas, selain untuk kepentingan penelitian.

Partisipan atau responden yang terlibat langsung dalam pemberian data telah memberikan izin data mereka di analisis orleh peneliti, karena peneliti terlebih dahulu meminta izin baik secara lisan maupun prosedural.

\section{HASIL DAN PEMBAHASAN}

Perkembangan Sosial merupakan perkembangan yang melibatkan kematangan seseorang, proses dimana orang menyesuaikan diri dan diterima di lingkungannya. Perkembangan sosial dapat dapat mulai distimulasi sejak anakanak agar dia belajar berinteraksi dengan lingkungannya. Dengan adanya proses sosialisasi dilingkungan anak, diharapkan anak dapat mulai peduli dan dapat diterima dengan utuh sesuai perannya di masyarakat. Untuk mengetahui perkembangan sosial anak di Kampung Cipertani, peneliti menyebar angket kepada 30 orang tua yang memiliki anak usia 5-6 tahun. Peneliti membuat 27 pernyataan. Alternative jawaban yang masing-masing mempunyai bobot nilai yang berbeda.

A. Latar Belakang Pendidikan Orang tua anak Usia 5-6 Tahun di Kampung Cipertani

Tabel 2. Data jumlah perbedaan latar belakang pendidikan orang tua

\begin{tabular}{cc}
\hline Pendidikan Orang Tua & $\begin{array}{c}\text { Jumlah } \\
\text { Responden }\end{array}$ \\
\hline SD Sederajat & 8 \\
SMP Sederajat & 6 \\
SMA Sederajat & 10
\end{tabular}

\begin{tabular}{cc} 
Perguruan Tinggi & 6 \\
\hline Jumlah & 30 \\
\hline Prosentase dan & pengkategorian
\end{tabular}

latar belakang pendidikan rang tua di ampung cipertani dapat dicari dengan rumus dibawah:

$$
P=\frac{F}{N} \times 100 \%
$$

Keterangan :

$\mathrm{P}=$ Angka prosentase

$\mathrm{F}=$ Frekuensi yang dicari

$\mathrm{N}=$ Number of case (Jumlah Responden) Setelah data berubah prosentase kemudian dikelompokan dalam kalimat yang bersifat kualitatif :

$$
\begin{array}{ll}
65 \%-100 \% & =\text { Baik } \\
35 \%-65 \% & =\text { Cukup Baik } \\
20 \%-35 \% & =\text { Kurang Baik } \\
<20 \%=\text { Tidak Baik }
\end{array}
$$

Tabel 3. Data Prosentase Latar belakang pendidikan orang tua

\begin{tabular}{|c|c|c|}
\hline Pendidikan & Frekuensi & Percent \\
\hline SD sederajat & 8 & $26.7 \%$ \\
\hline SMP sederajat & 6 & $20 \%$ \\
\hline SMA sederajat & 10 & $33,3 \%$ \\
\hline Perguruan Tinggi & 6 & $20 \%$ \\
\hline Dari & diatas & menunjukan
\end{tabular}

responden yakni orang tua yang berlatar pendidikan tamatan SD sederajat sebanyak 8 dengan presentasi 26,7\%, responden dengan berlatar pendidikan tamatan SMP sederajat sebanyak 6 dengan presentasi $20,0 \%$, selanjutnya responden dengan berlatar pendidikan lulusan SMA sederajat sebanyak 10 dengan presentase $33,3 \%$, dan responden berlatar pendidikan Perguruan Tinggi sebanyak 6 dengan presentase $20,0 \%$.

Berdasarkan standart yang ditetapkan diatas, maka nilai $33,3 \%$ berada diantara $20 \%$ - 35\%. Dengan demikian dapat disimpulkan bahwa tingkat pendidikan orang tua di Kampung Cipertani tergolong "Kurang Baik".

B. Perkembangan Sosial Anak Usia 5-6 Tahun di Kampung Cipertani

Dari hasil penelitian diatas, dapat diakumulasikan bahwa perkembangan sosial anak usia 5-6 tahun di Kampung Cipertani RT.005/RW.008 Desa Karangmekar Kecamatan Karangnunggal Kabupaten Tasikmalaya dengan prosentase tertinggi sebagai jawaban ideal yaitu $1.276,7 \%$ dengan jumlah item 
pertanyaan 26 item. Adapun pengkategorian skor perkembangan sosial anak yaitu:

$65 \%-100 \%=$ Berkembang Sangat Baik $35 \%-65 \%=$ Berkembang Sesuai Harapan $20 \%-35 \%=$ Masih Berkembang

Kurang dari $20 \%=$ Belum Berkembang Berdasarkan hasil analisis data didapat mean prosentase yaitu $47.18 \%$. jika dilihat pada tabel standar yang ditetapkan di atas, maka nilai 47,18\% berada di antara 35\% - 65\%. Dengan demikian dapat disimpulkan bahwa perkembangan sosial anak usia 5-6 tahun di Kampung Cipertani "Berkembang Sesuai Harapan”.

Tabel 4. Data ategori latar belakang pendidikdan orang tua terhadap kategori perkembangan sosial anak

Latar belakang pendidikan orang tua

\begin{tabular}{|c|c|c|c|c|c|}
\hline \multirow[b]{2}{*}{ Range } & \multicolumn{4}{|c|}{ orang tua } & \multirow{2}{*}{$\begin{array}{l}\text { Jumlahm } \\
\text { Respo } \\
\text { nden }\end{array}$} \\
\hline & SD & SMP & SMA & $\begin{array}{c}\text { Pergur } \\
\text { uan } \\
\text { Tinggi }\end{array}$ & \\
\hline Belum Berembang & 1 & 2 & 1 & & 4 \\
\hline Masih Berkembang & & 1 & 2 & & 3 \\
\hline $\begin{array}{l}\text { Berkembang } \\
\text { Sesuai Harapan }\end{array}$ & 5 & 3 & 6 & 4 & 18 \\
\hline $\begin{array}{l}\text { Berkembang } \\
\text { Sangat Baik }\end{array}$ & 2 & & 1 & 2 & 5 \\
\hline Jumlah & & & & & 30 \\
\hline
\end{tabular}

Berdasarkan data diatas bisa

diketahui bahwa orang tua yang berlatang belakang pendidikan lebih tinggi dapat membantu perkembangan sosial anaknya berkembang sangat baik. Hal tersebut dapat dilihat dari skor anak dengan orang tua berlatar belakang perguruan tinggi 4 anak mendapat predikat berkembang sesuai harapan dan 2 anak lainnya berpredikat "berkembang sesuai harapan".

\section{Uji Hipotesis}

Berdasarkan hasil analisis data dilihatapakah ada perbedaan perkembangan sosial anak usia 5-6 tahun dari tingat pendidikan orang tua tersebut.hasil analisis data, diperoleh nilai $\mathrm{P}(\mathrm{P}$-value $)=0,315$. Dengan demikian pada taraf nyata $=0,05$ kita dapat menerima Ho, sehingga kesimpulan yang didapatkan adalah tidak ada perbedaan yang bermakna rata-rata perkembangan sosial anak usia 5-6 tahun berdasarkan pada keeempat kelompok tingkat pendidikan orang tua tersebut.

Dapat disimpulkan tingkat pendidikan orang tua tidak dapat mempengaruhi perkembangan sosial anak usia 5-6 tahun. Serta jika dilihat dari segi perbedaan latar belakang pendidikan orang tua yang bersekolah lulusn SD sederajat maupun lulusan Perguruan tinggi mereka sama-sama bisa mengembangkan aspek perkembangan sosial anaknya usia 5-6 tahun.

\section{KESIMPULAN}

Berdasarkan hasil penelitian yang telah dilakukan pada orang tua beserta anak usia 5-6 tahun di kampung Cipertani, terkait latar belakang pendidikan orang tua terhadap perkembangan sosial anak usia 5-6 tahun, umlahmaka penelitian dapat menyimpulkan:

Latar belakang pendidikan orang tua yang memiliki anak usia 5-6 tahun di Kampung Cipertani cukup bervariasi dari 30 responden, ada yang lulusan $\mathrm{SD} /$ sederajat, $\mathrm{SMP}$ / sederajat, $\mathrm{SMA} /$ sederajat dan Perguruan tinggi. Tingkat pendidikan orang tua didominasi orang tua dengan tingkat pendidikan SMA/ sederajat yaitu sebanyak 10 responden. Hal ini dapat dilihat dari pengisisn angket yang telah diisi oleh para orang tua di Kampung Cipertani.

b. Perkembangan sosial anak usia 5-6 tahun di Kampung Cipertani berdasarkan data yang dihimpun dari angket yang disebar kepada 30 responden orang tua anak dapat dikategorisasikan perkembangan anak ada dalam tahap berkembang sesuai harapan. Hal ini dapat dibuktikan dari angket yang telah dianalisis dengan hasil prosentase sebesar $47,18 \%$ yang berad diantara $35 \%-65 \%$. Dengan hasil demikian maka dapat disimpulkan bawa perkembangan sosial anak usia 5-6 tahun di Kampung Cipertani "Berkembang Sesuai Harapan". Hal tersebut dapat dibuktikan dari hasil angket tentang perkembangan sosial anak yang dikumpulkan dari para orang tua.

c. Berdasarkan hasil analisis data yang diperoleh dan diuji dengan uji statistic anova hasil uji anoval latar belakang pendidikan SD sederajat mempunyai skor rata-rata 
perkembangan sosial anaknya yaitu 92.50, responden dengan latar belakang pendidikan SMP sederajat anaknya memiliki skor rata-rata perkembangan sosial sebesar 82.67, responden dengan latar belakang pendidikan SMA sederajat anaknya memiliki skor rata-rata perkembangan sosial sebesar 89.00, dan responden dengan latar belakang pendidikan Perguruan Tinggi anaknya memiliki skor rata-rata perkembangan sosial sebesar 96.50 .

\section{SARAN}

a. Bagi orang tua dengan latar pendidikan apapun dapat memaksimalkan tingkat perkembangan sosial anak usia 5-6 tahun dengan upaya stimmulasi dan pemodelan yaitu orang tua sebagai contoh yang dapat ditiru anak. Diharapkan orang tua mau tetap terus belajar bagaimana memaksimalkan perkembangan anak dan tidak membatasi perkembangan sosial anak, karena orang tua sangat berpengaruh dan orang terdekat bagi anaknya untuk dijadikan panutan bersosialisasi dilingkungan sekitarnya.

b. Bagi peneliti selanjutnya hendaknya menggunakan teknik pengumpulan data observasi untuk mengukur perkembangan sosial anak dalam memudahkan pengamatan dan pengukuran yang seragam oleh satu atau lebih observer. Karena penelitian ini dilakukan saat kondisi pandemi tidak dimungkinkan untuk melakukan observasi ke sekolah maka dipilih alternative angket.

c. Bagi guru semakin memberikan stimulasi sosial disekolah bagi perkembangan anak untuk membantu para orang tua mengembangkan perkembangan sosial anak yang tidak didapatkannya dirumah.

\section{DAFTAR PUSTAKA}

Ayuningsih, Diah. (2010). Psikologi Perkembangan Anak. Yogyakarta: Pustaka Larasati.

Creswell, J. W. (2013). Pendekatan Kualitatif, Kantitatif, dan Mixed. Yogyakarta: Pustaka Pelajar.

Mardapi, Djemari. (2008). Teknik Penyusunan Instrumen dan Nontes. Yogyakarta: Mitra Cendikia Press

Huwaina, Inarah. (2018). Perkembangan Sosial Emosional Anak Melalui Permainan Gerak dan Lagu Di Taman Kanak-Kanak Assalam I Sukarame
Bandar Lampung. Skripsi : Universitas Islam Negeri Raden Intan Lampung.

Hurlock. (1991). Perkembangan Anak. Jakarta: Penerbit Erlangga.

Hurlock. (1991). Perkembangan Anak. Jilid 1. Edisi ke-6. Jakarta: Penerbit Erlangga.

Mahanani, Mamik. (2015). Hubungan Perhatian Orang Tua dengan Perkembangan Sosial Anak Usia 4-5 Tahun di Desa Birit Kecamatan Wedi Kabupaten Klaten Tahun 2015. Skripsi : Universitas Negeri Yogyakarta.

Mayar, Farida. (2013). Perkembangan Sosial Anak Usia Dini Sebagai Bibit untuk Masa Depan Bangsa. Jurnal Al-Ta'lim, Jilid 1, Nomor 6 hlm. 459-464.

Misbahudin. \& Iqbal Hasan. (2013). Analisis Data Penelitian dengan Statistik. Jakarta: Bumi Aksara.

Muhidin, A. S. \& Abdurrahman, M. (2009). Analisis Korelasi, Regresi dan Jalur dalam Penelitian. Bandung : Pustaka Setia.

Nursalam. (2008). Konsep dan Penerapan Metodologi Penelitian Ilmu Keperawatan. Jakarta: Salemba Medika.

Putri, Y. P. (2016). Pengaruh Model Pembelajaran Kooperatif Tipe Teams Games Tournament (TGT) Terhadap Motivasi Belajar IPS Siswa Kelas VIII MTS. Negeri 1 Tulang Bawang. Lampung : Universitas Lampung

Rachmawati, Yeni. (). Perkembangan Sosial Emosional pada Anak Usia Taman Kanak-kanak. PAUD4103/MODUL 1.

Rukaesih, M. \& Cahya, U. (2015). Metode Penelitian Pendidikan. Jakarta : PT. Raja Gravindo.

Purwanto. (2010). Instrumen Penelitian Sosial dan Pendidikan: Pengembangan dan Pemanfaatan. Yogyakarta: Pustaka Pelajar.

Sakinah, L. F. (2018). Pengaruh Latar Belakang Pendidikan Orang Tua Terhadap Kedisiplinan Ibadah Sholat Siswa Kelas VIII MTSN 2 Lamongan. Skripsi : Universitas Islam Negeri Sunan Ampel SurabayaUnaradjan, D. D. (2019). Metode Penelitian Kuantitatif. Jakarta: Penerbit Unika Atma Jaya.

Sudaryono, dkk. (2013). Pengembangan Instrumen Penelitian Pendidikan. Yogyakarta: Graha Ilmu.

Sugiono. (2007). Metode penelitian pendidikan: (pendekatan. kuantitatif, kualitatif, dan R\&D). Bandung: Alfabeta.

Sugiyono. (2011). Metode penelitian pendidikan: (pendekatan. kuantitatif, kualitatif, dan R\&D). Bandung: Alfabeta. 
Sugiyono. (2013). Metode Penelitian Kuantitatif, Kualitatif Dan R\&D. Bandung : Alfabeta.

Sujiono, Y. Nurani. (2009). Konsep Dasar Pendidikan Anak Usia Dini. Jakarta: PT Indeks.

Suyadi \& Maulidya Ulfah. (2013). Konsep Dasar PAUD. Bandung: Remaja. Rosdakarya.

Undang-Undang Nomor 20 Tahun 2003 Tentang Sistem Pendidikan Nasional.

Widianto, Joko. (2010). SPSS For Windows untuk Analisis Data Statistik dan Penelitian. Surakarta: BP-FKIP UMS.

Yeni Krismawati. (2014). Teori Psikologi Perkembangan Erik H. Erikson dan Manfaatnya. Jurnal Teologi dan Pendidikan Agama Kristen. Vol. 2(1) hlm.

Yusuf, Syamsu. (2001). Psikologi Perkembangan Anak dan Remaja. Bandung: PT.Remaja Rosdakarya 